\title{
Fenitrothion Alters Sperm Characteristics in Rats: Ameliorating Effects of Palm Oil Tocotrienol-Rich Fraction
}

\author{
Izatus Shima TAIB, Siti Balkis BUDIN, Ahmad Rohi GHAZALI, Putri Ayu JAYUSMAN, and \\ Jamaludin MOHAMED \\ Program of Biomedical Science, School of Diagnostic and Applied Health Sciences, Faculty of Health Sciences, \\ Universiti Kebangsaan Malaysia, Jalan Raja Muda Abdul Aziz, 50300 Kuala Lumpur, Malaysia
}

\begin{abstract}
Exposure to organophosphate insecticides such as fenitrothion (FNT) in agriculture and public health has been reported to affect sperm quality. Antioxidants may have a potential to reduce spermatotoxic effects induced by organophosphate. The present study was carried out to evaluate the effects of palm oil tocotrienol-rich fraction (TRF) in reducing the detrimental effects occurring in spermatozoa of FNT-treated rats. Adult male Sprague-Dawley rats were divided into four equal groups: a control group and groups of rats treated orally with palm oil TRF $(200 \mathrm{mg} / \mathrm{kg})$, FNT $(20 \mathrm{mg} / \mathrm{kg})$ and palm oil TRF $(200 \mathrm{mg} / \mathrm{kg})$ combined with FNT $(20 \mathrm{mg} / \mathrm{kg})$. The sperm characteristics, DNA damage, superoxide dismutase (SOD) activity, and levels of reduced glutathione (GSH), malondialdehyde (MDA), and protein carbonyl (PC) were evaluated. Supplementation with TRF attenuated the detrimental effects of FNT by significantly increasing the sperm counts, motility, and viability and decreased the abnormal sperm morphology. The SOD activity and GSH level were significantly increased, whereas the MDA and PC levels were significantly decreased in the TRF+FNT group compared with the rats receiving FNT alone. TRF significantly decreased the DNA damage in the sperm of FNT-treated rats. A significant correlation between abnormal sperm morphology and DNA damage was found in all groups. TRF showed the potential to reduce the detrimental effects occurring in spermatozoa of FNT-treated rats.
\end{abstract}

Key words: antioxidant, organophosphate, oxidative stress, spermatozoa, vitamin $E$

\section{Introduction}

Various environmental toxicants disrupt the human male reproductive system by decreasing semen quality [3]. A considerable number of toxic agents including organophosphate (OP) have harmful effects on sperm [21]. Fenitrothion [O,O-dimethyl-O-(3-methyl-4-nitrophenyl) phosphorothioate] (FNT) is a broad-spectrum OP used in agriculture and public health [48]. Residual amounts of this compound have been found in soil, water, and vegetables due to its widespread usage [52]. The contamination of FNT in the environment and food is often considered unavoidable.

There are several reports on adverse reproductive effects resulting from occupational exposure to OP $[27,33,55]$. OP compounds were shown to decrease sperm quality such as seminal volume, concentration, sperm motility, and morphology in agricultural workers either directly or indirectly exposed to the compounds [55]. Increased frequency of sperm aneuploidy and sperm DNA fragmentation were reported in workers exposed to OP mixtures [27]. 
FNT has been found to cause oxidative damage in rat sperm and testes due to the high level of reactive oxygen species (ROS) formation [44]. Spermatozoa have been proposed as target cells of OP due to their membranes, which are rich in polyunsaturated fatty acids (PUFAs) [33]. The lack of cytoplasmic defensive enzymes in mature sperm also causes the cells to become more sensitive to any ROS. Oxidative stress may lead to sperm DNA damage, which has been found to be a novel indicator in investigating the effects of toxicants on male reproductive health [2]. Furthermore, sperm analyses such as analyses of sperm count, motility, viability, and morphology are the most reliable end-point tests for male reproductive status [47].

Studies have been performed to determine the protective effects of antioxidants against the reproductive system damage induced by OP $[16,37,49]$. Antioxidants such as vitamin $\mathrm{E}$, vitamin $\mathrm{C}$, alpha lipoic acid, and melatonin possess efficacy in reducing lipid peroxidation in biological systems by inhibiting the formation of free radicals [46]. Previous researchers found that commercial vitamin E, which consists of only $\alpha$-tocopherol, showed the potential to reduce the toxic effects of OP exposure, but they concluded that this type of vitamin $\mathrm{E}$ is not completely protective $[49,50]$. $\alpha$-Tocopherol has been long recognized as the most important lipophilic radical chain-breaking antioxidant. Recently, there has been growing evidence indicating that tocotrienol possessing superior antioxidant [32], neuroprotective [20], anticancer (eg; colon, breast and liver cancer cells) $[13,36,54]$, antiangiogenic [41], and hypocholesterolemic [39] health effects compared with $\alpha$-tocopherol. Therefore, the combination of these two types of vitamin E might give a better protective effect.

Palm oil naturally consists of tocopherol and tocotrienol and is known as palm oil tocotrienol-rich fraction (TRF). Mixtures of tocotrienol and tocopherol from palm oil showed better protection against free radical-induced bone damage in rats compared with pure $\alpha$-tocopherol [1]. Palm oil TRF at the dose of $200 \mathrm{mg} / \mathrm{kg}$ also showed a protective effect against many pathological conditions including diabetes-induced atherosclerosis and red blood cells membrane damage $[8,26]$ and OP-induced toxicity in the kidney and pancreas $[6,7]$. Besides, TRF at the same dose did not cause any oxidative damage in normal rats $[6,7,26]$. To our knowledge, the protective effects of TRF at a dose of $200 \mathrm{mg} / \mathrm{kg}$ on sperm damage induced by FNT have not been established yet. There- fore, the main aim of this study was to demonstrate the potential protective effects of palm oil TRF at a dose of $200 \mathrm{mg} / \mathrm{kg}$ in reducing the toxic effects of FNT-induced sperm damage in rat.

\section{Materials and Methods}

\section{Animals}

Twenty-eight adult male Sprague-Dawley rats (Rattus norvegicus), weighing between 230 and $250 \mathrm{~g}$ were obtained from the Laboratory Animal Resource Unit, Faculty of Medicine, Universiti Kebangsaan Malaysia (UKM), Kuala Lumpur, Malaysia, and acclimatized for a week prior to treatment. The rats were housed in plastic cages and were provided with standard pellet diet and water ad libitum. All rats were exposed under standard environmental conditions (12 h light / dark cycles, 25$28^{\circ} \mathrm{C}$ ) throughout the study period. The experiment was conducted after receipt of ethical approval from the UK M Animal Ethics Committee (resolution number: FSKB/ BIOMED/2010/BALKIS/14-JULY/311-AUGUST2010-JULY-2011).

\section{Chemicals}

FNT was purchased from Supelco Analytical (Belefonte, PA, USA ; lot number: LB75917). The purity of the chemicals used in this study was $99.9 \%$. Palm oil TRF (Gold Tri.E 70; batch no: SB1004200070) consisting of $22.55 \% \alpha$-tocopherol, $25.08 \% \alpha$-tocotrienol, $4.74 \% \beta$-tocotrienol, $27.82 \% \gamma$-tocotrienol, and $19.81 \%$ $\delta$-tocotrienol was purchased from Sime Darby, Malaysia.

\section{Animal treatment schedule}

Rats were randomly divided into four groups with seven rats in each group: (I) the control group, which received corn oil (Vecorn, Yee Lee Edible Oils Sdn Bhd, Malaysia; $1 \mathrm{ml} / \mathrm{kg}$ ); (II) the TRF group, which received palm oil TRF dissolved in corn oil at a dose of $200 \mathrm{mg} / \mathrm{kg}$ ( $1 \mathrm{ml} / \mathrm{kg}$ ); (III) the FNT group, which received FNT dissolved in corn oil at a dose of $20 \mathrm{mg} / \mathrm{kg}\left(1 / 30 \mathrm{LD}_{50}\right.$; $1 \mathrm{ml} / \mathrm{kg}$ ); and (IV) the TRF + FNT group, which received palm oil TRF $(200 \mathrm{mg} / \mathrm{kg} ; 1 \mathrm{ml} / \mathrm{kg}) 30 \mathrm{~min}$ prior to the administration of FNT $(20 \mathrm{mg} / \mathrm{kg} ; 1 \mathrm{ml} / \mathrm{kg})$. All the chemical substances (FNT and palm oil TRF) were administered once daily in the morning between 9.00 and 10.00 a.m. by oral gavage for 28 consecutive days.

At the end of the study, rats were fasted overnight and anesthetized with diethyl ether. All animals were sacri- 
ficed to expose their epididymides. Both left and right cauda epididymides were placed immediately in $2 \mathrm{ml}$ of Hank's Buffered Salt Solution (HBSS) enriched with $0.5 \% \mathrm{BSA}$ and pre-warmed at $37^{\circ} \mathrm{C}$. The cauda epididymides were then cut into small pieces and centrifuged at $1,000 \mathrm{rpm}$ at $4^{\circ} \mathrm{C}$ for $3 \mathrm{~min}$ in order to obtain the sperm for further analysis.

\section{Sperm characteristics analysis}

The sperm characteristics were evaluated by the method of Seed [38]. Ten microliters of sperm suspension was immediately analyzed for motility using a Makler counting chamber. A routine gold standard method was used in assessing the viability of sperm based on the ability of eosin to penetrate the membrane of nonviable cells. The viability of sperm is presented as a percentage (\%). For determination of sperm count, the number of sperm in $10 \mu \mathrm{l}$ of sperm suspension was calculated using a Makler counting chamber under 10X magnification using a light microscope. The obtained results were expressed as $10^{6}$ cells per $\mathrm{ml}$. The percentage of abnormal sperm morphology was calculated using a thin smear of sperm suspension. The dried smear was fixed in an absolute ethanol for $5 \mathrm{~min}$. Then, the slide was immersed in Diff-Quik Stain I and II for 5 min each. Two hundred sperms were examined per animal to measure the morphological abnormalities under oil immersion. The data are presented as the percentage of abnormal sperm morphology.

\section{Oxidative stress evaluation}

Epididymal sperm suspension was centrifuged at $3,500 \mathrm{rpm}$ for $10 \mathrm{~min}$ at $4{ }^{\circ} \mathrm{C}$, and the resulting pellet was resuspended in $0.9 \% \mathrm{NaCl}$. The sperm suspension was homogenized using a glass-Teflon homogenizer under cold conditions. Sperm homogenate was further aliquoted for superoxide dismutase (SOD), reduced glutathione (GSH), malondialdehyde (MDA), and protein carbonyl (PC) determination. Protein concentration was assessed using the Lowry method [24].

SOD activity was evaluated by its ability to inhibit the ferricytochrome reduction according to the method of Beyer and Fridovich [5]. Twenty microliters of sperm homogenate was mixed with substrate mixtures [PBS (EDTA), L-methionine, NBT.2HCl, Triton-X] and incubated in an aluminium box under a 20 watt lamp for $7 \mathrm{~min}$. Colour development was measured at $560 \mathrm{~nm}$, and the activity of SOD was expressed as units of en- zyme/mg protein/min, with one unit of enzyme inhibiting $50 \%$ of nitro blue tetrazolium (NBT). GSH level was measured based on the Ellman [15] method. The sperm homogenate was mixed with reaction buffer $(\mathrm{pH} 8.0)$ and 5,5'-dithiobis-2-nitrobenzoic acid (DTNB) for 15 mins. Colour development was measured at $412 \mathrm{~nm}$, and the result was expressed as $\mathrm{mmol} / \mathrm{mg}$ protein.

MDA was measured based on the formation of thiobarbituric acid reactive substances (TBARS) when MDA in the sample reacted with thiobarbituric acid at $100^{\circ} \mathrm{C}$ [43]. Pink color development was measured at $532 \mathrm{~nm}$, and the MDA concentration was presented as $\mathrm{mM} / \mathrm{mg}$ protein. PC content in sperm homogenate was measured by the method of Levine [23] with some modifications. An equal volume of sample was added with $20 \%$ of TCA solution and was allowed to stand on ice for $15 \mathrm{~min}$ for protein precipitation. Then, the solution was centrifuged at $15,000 \times \mathrm{g}$ at $4^{\circ} \mathrm{C}$ for $5 \mathrm{~min}$. The supernatant was discarded, the protein pellet was added to $10 \mathrm{mM} 2,4$-dinitrophenylhydrazine (DNPH):2 $\mathrm{M} \mathrm{HCl}(1: 1)$, and the solution was then placed in the dark at room temperature for $1 \mathrm{~h}$. Five hundred microliters of 20\% TCA was added into the solution, and the solution was then left to stand on ice for $15 \mathrm{~min}$. Then, the solution was centrifuged at $15,000 \times \mathrm{g}$ at $4^{\circ} \mathrm{C}$ for $5 \mathrm{~min}$. The supernatant was discarded, and the protein pellet was washed with $20 \%$ TCA and centrifuged. The pellet was then washed with ethanol:ethyl acetate (1:1) 3 times, resuspended in $6 \mathrm{M}$ guanidine hydrochloride (dissolved in $20 \mathrm{mM}$ phosphate buffer, $\mathrm{pH} 2.3$ ), and incubated at $37^{\circ} \mathrm{C}$ for 15 mins. Finally, the protein carbonyl content was measured at $366 \mathrm{~nm}$, and the data were expressed as $\mathrm{nmol} / \mathrm{mg}$ protein.

\section{Detection of sperm DNA damage by comet assay}

The sperm comet assay was performed by the method described by Trivedi et al. [47] with some modifications. Sperm suspension was diluted in 0.01 M PBS, pH 7.4, to obtain 1-3 $\times 10^{4}$ sperms per $\mathrm{ml}$. The diluted sperm suspension $(10 \mu 1)$ was suspended in $80 \mu$ l of $0.6 \%$ low melting point agarose (LMA). Then, $80 \mu 1$ of the sperm suspension was applied onto the surface of a microscope slide pre-coated with $0.6 \%$ normal melting point agar (NMA). The agar was allowed to solidify for $15 \mathrm{~min}$ at room temperature. The agar slides were dipped in cell lysis buffer [2.5 M NaCl, $100 \mathrm{mM} \mathrm{Na} 2$ EDTA. $2 \mathrm{H}_{2} \mathrm{O}$, $10 \mathrm{mM}$ Tris] containing $1 \%$ Triton-X and DMSO for $1 \mathrm{~h}$ at $4{ }^{\circ} \mathrm{C}$. The slides were then transferred into a second lysis buffer containing $10 \mathrm{mM}$ DTT and incubated for 
$24 \mathrm{~h}$ at room temperature. Following the second lysis, slides were transferred into a third lysis buffer containing $0.1 \mathrm{mg} / \mathrm{ml}$ proteinase- $\mathrm{K}$ and incubated for $24 \mathrm{~h}$ at $37^{\circ} \mathrm{C}$. All the above procedures were conducted under dark conditions.

Slides were placed horizontally in electrophoresis buffer ( $\mathrm{pH}$ 12-13) containing $300 \mathrm{mM} \mathrm{NaOH}$ and $1 \mathrm{mM}$ EDTA in an electrophoresis tank (Nyx Technik, San Diego, CA, USA) for $20 \mathrm{~min}$ to allow the DNA to unwind. Electrophoresis was conducted at $300 \mathrm{~mA}$ and $25 \mathrm{~V}$ for $1 \mathrm{~h}$ at $4^{\circ} \mathrm{C}$. Following electrophoresis, slides were neutralized 3 times for 5 min each. Fifty microliters of ethidium bromide (EtBr) was dropped on the slide, and cover slips were placed on the slides before imaging analysis under a fluorescent microscope (BX51TR32FB3-F01, Olympus Corporation, Japan). A total of 50 images per slide were captured and analyzed using the CometScore software, and the parameters for DNA damage included tail length (TL), tail DNA (\%), tail moment (TM), and olive tail moment (OTM).

\section{Statistical analysis}

Data were expressed as means \pm SEM. The differences among experimental groups were statistically evaluated using one-way analysis of variance (ANOVA) followed by the Tukey test. Correlation of abnormal sperm morphology and DNA damage was performed using bivariate correlation analysis. All results were considered statistically significant at $P<0.05$, and all analyses were performed using the Statistical Packages for the Social Sciences (SPSS) version 17.0.

\section{Results}

\section{Sperm characteristics}

The sperm characteristics of the experimental groups are shown in Table 1. Sperm count, motility, and viability in the FNT-treated group were significantly decreased compared with in the control and TRF groups $(P<0.01)$.
However, FNT-treated rats supplemented with TRF showed a significant increase in sperm count, motility, and viability compared with the FNT group $(P<0.05)$. The percentage of abnormal sperm morphology was significantly higher in FNT-treated rats compared with the control and TRF groups $(P<0.01)$. However, TRF showed the potential to reduce the percentage of abnormal sperm morphology significantly compared with the FNT group $(P<0.05)$.

\section{SOD activity and GSH levels}

Figure 1 shows the SOD activity and GSH levels of epididymal sperm in the experimental groups. The SOD activity and GSH levels in the FNT-treated group were significantly lower compared with those of the control and TRF groups $(P<0.01)$. The SOD activity was higher in the TRF+FNT group when compared with that in the FNT group, but there were no statistically different. TRF+FNT rats showed a significant increase in GSH levels compared with the FNT group $(P<0.05)$ after the 28-day treatment.

\section{MDA and PC levels}

The MDA and PC levels of epididymal sperm in the experimental groups are shown in Fig. 2. The MDA and PC levels were significantly higher in the FNT group compared with the control and TRF groups $(P<0.01)$. The MDA level was insignificantly lower in the TRF+FNT group compared with in the rats receiving FNT alone. Meanwhile, the PC level in the TRF+FNT group was significantly lower when compared with that in the FNT group $(P<0.05)$.

\section{Sperm DNA damage}

FNT led to sperm DNA damage by significantly increasing the comet assay parameters such as the TL, TM, OTM, and \%DNA compared with the control and TRF groups $(P<0.001$; Fig. 3$)$. However, supplementation with TRF significantly lowered the sperm DNA damage

Table 1. Effects of TRF on epididymal sperm characteristics of FNT-treated rats

\begin{tabular}{lcccc}
\hline \multicolumn{1}{c}{ Parameter } & Control & TRF & FNT & TRF + FNT \\
\hline Cauda Sperm Count $\left(\times 10^{6}\right.$ cells $)$ & $56.38 \pm 5.22$ & $66.33 \pm 7.67$ & $23.59 \pm 3.29^{\mathrm{a}, \mathrm{b}}$ & $51.67 \pm 7.72^{\mathrm{c}}$ \\
Sperm Motility (\%) & $67.67 \pm 5.28$ & $70.89 \pm 3.88$ & $42.57 \pm 5.75^{\mathrm{a}, \mathrm{b}}$ & $62.98 \pm 4.43^{\mathrm{c}}$ \\
Sperm Viability (\%) & $73.39 \pm 1.40$ & $71.95 \pm 3.39$ & $32.35 \pm 3.22^{\mathrm{a}, \mathrm{b}}$ & $59.60 \pm 1.65^{\mathrm{c}}$ \\
Sperm Head Abnormality (\%) & $10.48 \pm 1.14$ & $10.16 \pm 1.28$ & $28.78 \pm 5.25^{\mathrm{a}, \mathrm{b}}$ & $12.22 \pm 2.08^{\mathrm{c}}$ \\
\hline
\end{tabular}

The values are expressed as means \pm SEM. aSignificant difference as compared with the control group at $P<0.01$. ' Significant difference as compared with the TRF group at $P<0.01$. 'Significant difference as compared with the FNT group at $P<0.05$. 


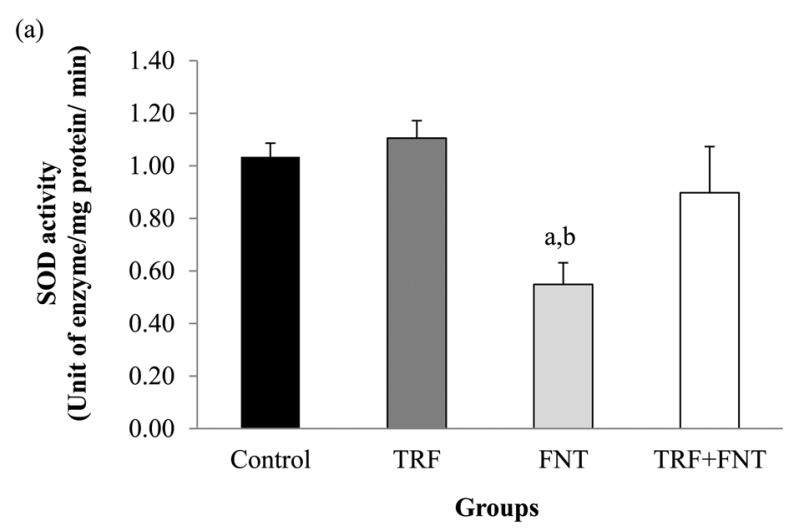

(b)

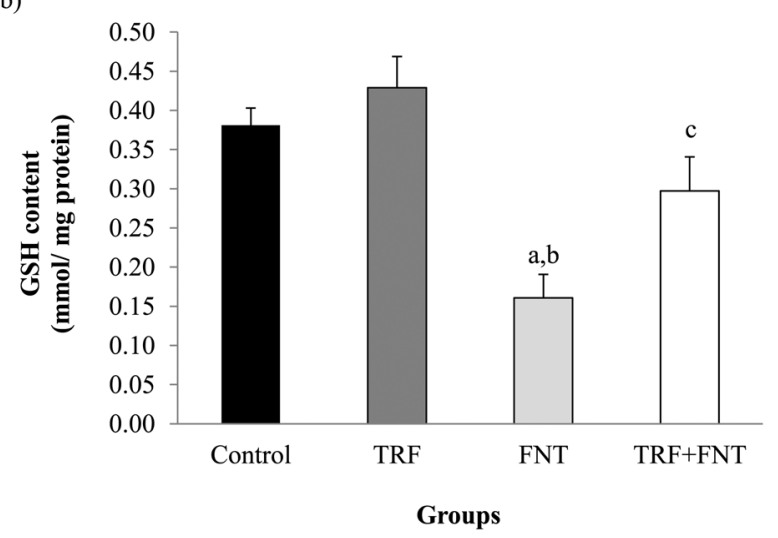

Fig. 1. Effects of TRF on (a) SOD activity and (b) GSH content in epididymal sperm of FNT-treated rats. The values are expressed as means \pm SEM, and $P<0.05$ was the level of

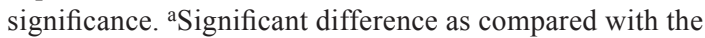
control group at $P<0.01$. 'bignificant difference as compared with the TRF group at $P<0.01$. 'Significant difference as compared with the FNT group at $P<0.05$.

compared with that in the FNT group alone in all investigated parameters $(P<0.01)$. Figure 4 shows the DNA migration pattern in rat sperm nuclei of the experimental groups after 28 days of treatment. These results support the findings mentioned above.

A significant correlation was found between abnormal sperm morphology and sperm DNA damage in the experimental groups using regression analysis $(P<0.01$; Fig. 5). Positive correlations were observed between the percentages of abnormal sperm morphology and the TL $(\mathrm{r}=0.826, P<0.001), \mathrm{TM}(\mathrm{r}=0.779, P<0.001)$, OTM $(\mathrm{r}=0.767, P<0.001)$, and $\%$ DNA $(\mathrm{r}=0.789, P<0.001)$ in the experimental groups.
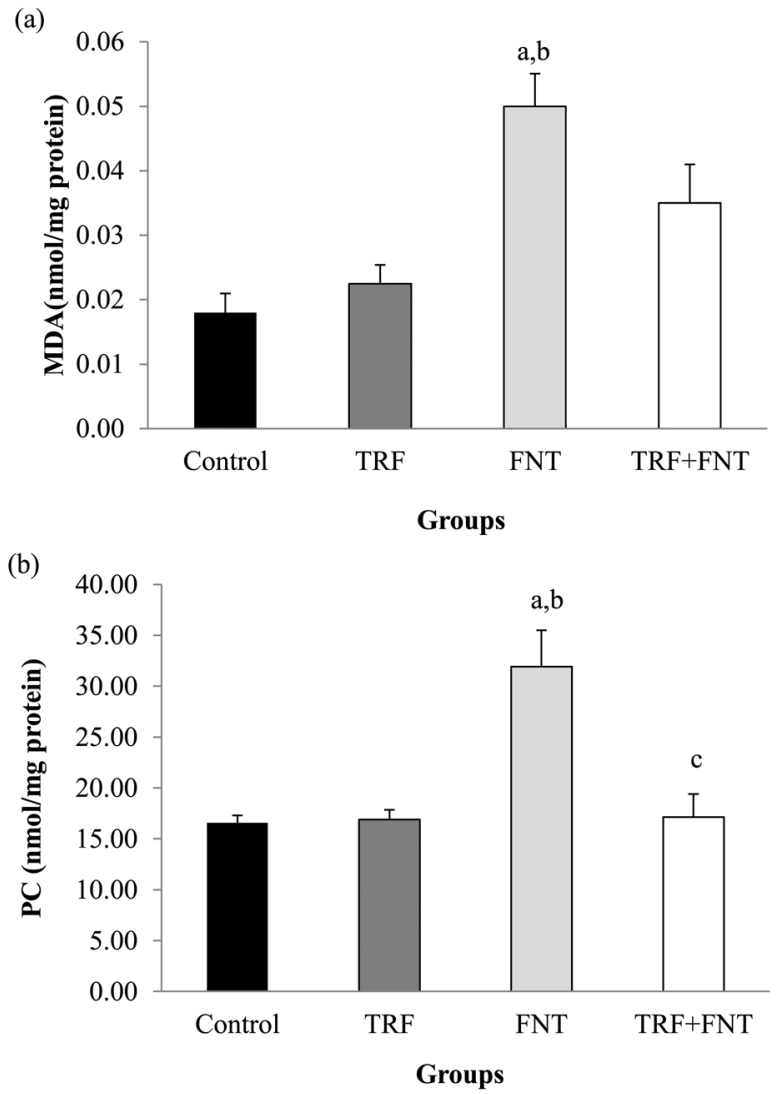

Fig. 2. Effects of TRF on (a) MDA and (b) PC in epididymal sperm of FNT-treated rats. The values are expressed as means \pm SEM, and $P<0.05$ was the level of significance. ${ }^{\text {aSignificant }}$ difference as compared with the control group at $P<0.01$. ${ }^{\mathrm{b}}$ Significant difference as compared with the TRF group at $P<0.01$. 'Significant difference as compared with the FNT group at $P<0.05$.

\section{Discussion}

Exposure to OP is a health risk for living organisms. Humans can be exposed to these toxic compounds either due to occupational exposure or accidental consumption of contaminated food, which affects sperm quality [49]. Defect of sperm quality has become one of the etiologies contributing to male infertility [3]. In the present study, FNT was proven to cause alterations in sperm characteristics by decreasing the sperm count, motility, and viability and altering the normal sperm morphology. These results support previous research that found OP exposure reduced the sperm quality in animal and human studies [44, 49, 55].

FNT has been reported to be an antiandrogenic agent that might alter spermatogenesis in the rat testis [45]. 

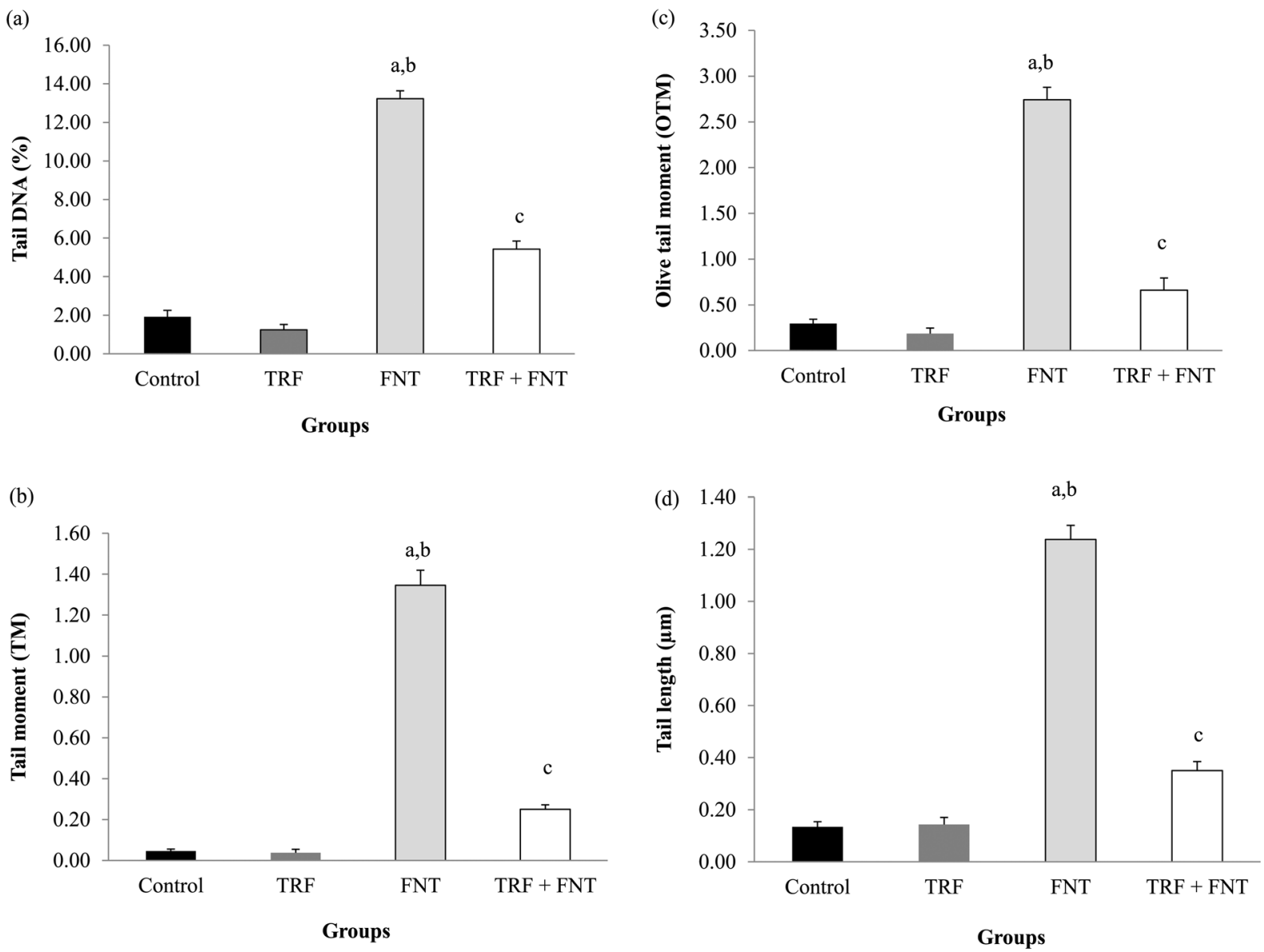

Fig. 3. Effects of TRF on DNA damage, (a) tail DNA, (b) tail moment, (c) olive tail moment, and (d) tail length, in epididymal sperm

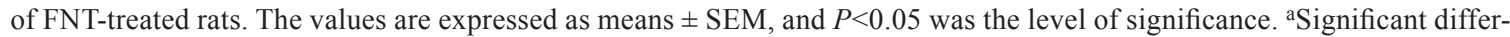
ence as compared with the control group at $P<0.01$. ${ }^{b}$ Significant difference as compared with the TRF group at $P<0.01$. ${ }^{\mathrm{c}}$ Significant difference as compared with the FNT group at $P<0.01$.

Disruptions in spermatogenesis may cause a reduction in sperm count and alteration in the meiotic phase of germ cells, thus leading to DNA damage. Sperm DNA damage can be characterized by the sperm head morphological abnormality [47]. In fact, the sperm head morphological abnormality can be used as an indicator in assessing the end stage of DNA damage induced by genotoxic agents [9]. Besides, an increase in ROS formation might also reduce sperm quality [31]. ROS can directly affect the activity of mitochondria enzymes, decrease the ability of cells to maintain their ATP levels, and disrupt the structure of microtubules in sperm, thus damaging their normal functions [30]. A slight deprivation of ATP may decrease sperm motility [4]. This mechanism might explain the sperm quality defects in FNT-treated rats, that is, by decreasing sperm motility and viability and increasing the abnormal sperm mor- phology. Administration of FNT at a smaller dose in the diet may also cause a mild decrease in sperm concentration, motility, and morphology [29]. In contrast, dichlorvos induction has been found to reduce the percentage of sperm motility without causing any alterations in sperm count and morphology. This may be due to the inability of dichlorvos to maintain ATP synthesis in the mitochondria of rat sperm [31].

FNT was proven to cause oxidative stress in epididymal sperm by inhibiting the SOD activity and GSH level as well as by increasing the levels of MDA and PC. These results were in line with previous research that found administration of FNT induced oxidative stress in the liver, kidney, and testis [14, 44]. Besides, exposure to environmental toxicants such as OP may also generate oxidative stress resulting in the inhibition of enzymatic antioxidant activity and an increase in lipid peroxidation 

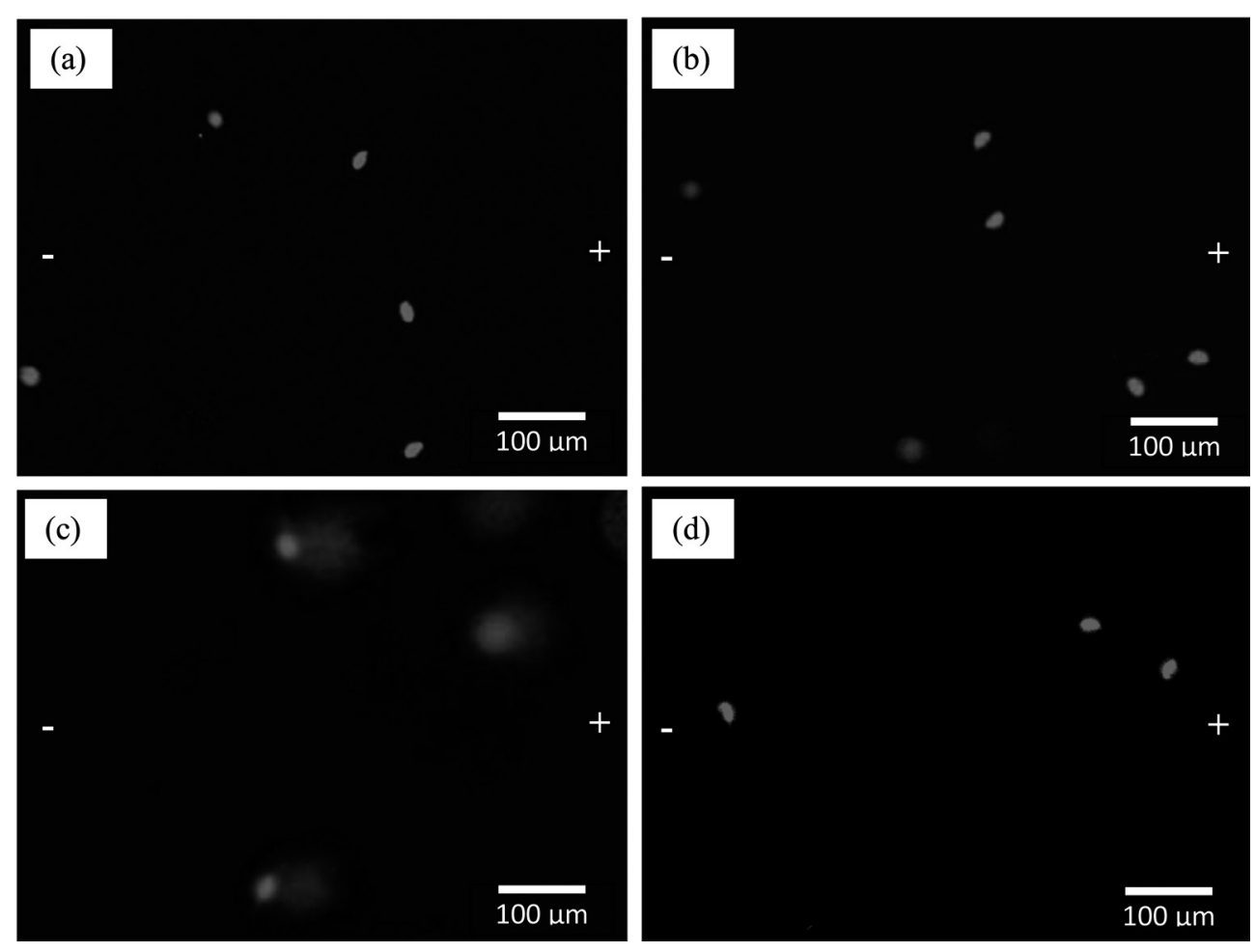

Fig. 4. Photomicrographs showing the effects of TRF on the DNA migration pattern in rat sperm heads treated with FNT. The "-" and "+" symbols represent cathode and anode respectively during electrophoresis. Dye: EtBr. (a) Sperm head nuclei from the control group, (b) sperm head nuclei from the TRF group, (c) sperm head nuclei from the FNT group, and (d) sperm head nuclei from the TRF + FNT group.

in rat spermatozoa $[3,22]$.

FNT undergoes the biotransformation process in the liver through the formation of reactive metabolite by CYP450 activity, which is known as fenitrooxon [12]. FNT and fenitrooxon may cross the epididymal epithelium based on its lipophilic properties and may reach the sperm in the epididymis [37]. This might explain how the FNT might cross the epididymal membrane and caused damage to sperm. Besides the metabolism pathway, high energy consumption coupled with inhibition of oxidative phosphorylation might also explain the generation of ROS in OP toxicity [28].

SOD plays an important role in the first line of the defence mechanism that catalyzes the conversion of the superoxide anion into $\mathrm{H}_{2} \mathrm{O}_{2}$ and reduces the formation of ROS. GSH is a sensitive indicator for oxidative stress and plays an important role in maintaining cell integrity [42]. Polychlorinated biphenyl decreases the activity of SOD and the GSH content in rat sperm by decreasing the synthesis of these antioxidants and increases the degradation and inactivation of SOD and GSH [22].
Decreased SOD activity has also been induced in rat sperm by dimethoate. The utilization of endogenous antioxidants in combating ROS might explain the reduction of antioxidant levels in rat sperm [18]. This might also explain the decreased antioxidant levels in rat sperm induced by FNT.

Oxidative damage of sperm induced by OP can be described through the increased levels of MDA and PC. MDA has been recognized as an indicator for lipid peroxidation [25]. Increased MDA levels may influence the formation of PC through oxidation of the - $\mathrm{SH}$ group [42]. This result supports previous research that found OP increased the MDA levels of rat sperm [3]. Therefore, it has been suggested that FNT causes oxidative damage in rat sperm by increasing the formation of MDA and PC.

Besides of causing damage to lipids, proteins, and carbohydrates, ROS can also cause oxidative damage to DNA [51]. The involvement of ROS in DNA strand breaks [17] and DNA base oxidation [11] may lead to sperm DNA damage. This might explain the DNA dam- 
(a)

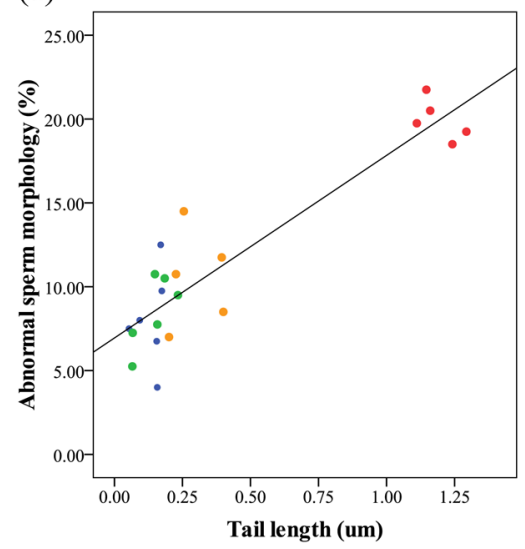

(c)

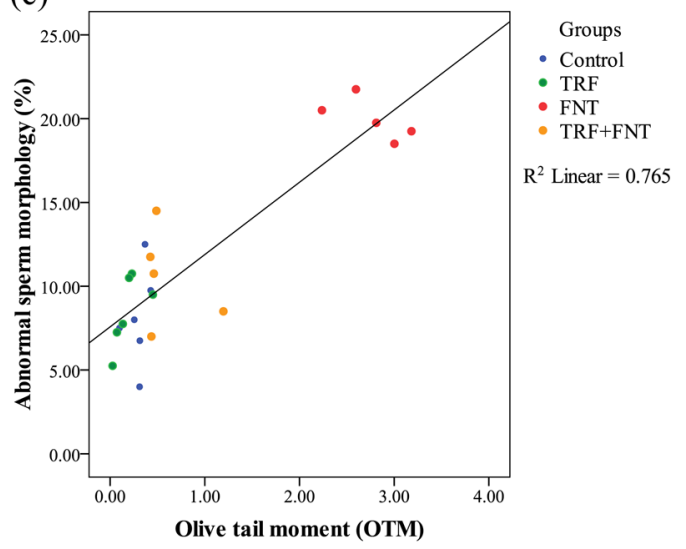

(b)

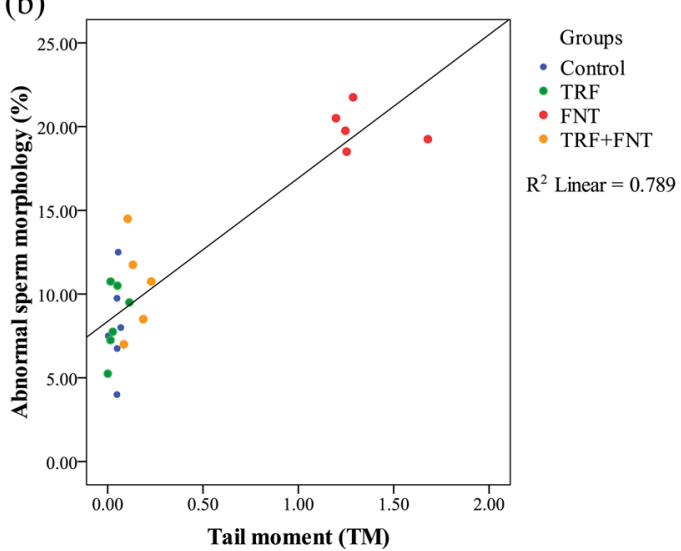

(d)

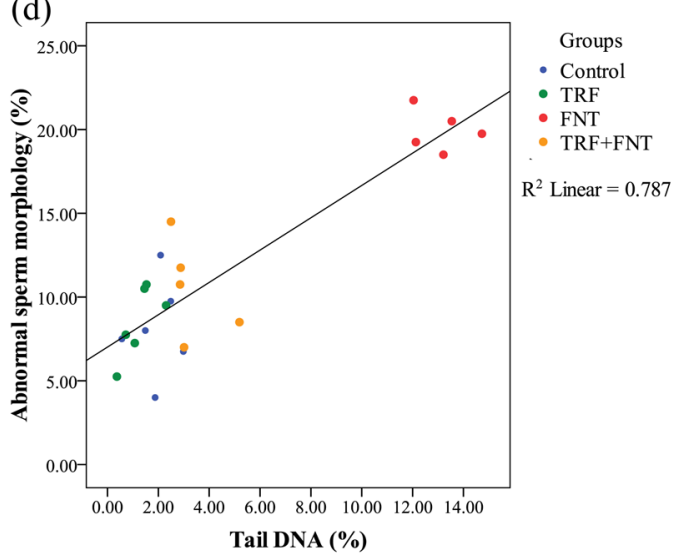

Fig. 5. Linear regression analysis showing the positive correlation of the abnormal sperm head morphology and sperm DNA damage in the experimental groups. (a) Correlation between abnormal sperm head morphology and tail length of treated rats with $\mathrm{r}^{2}=0.822(P<0.01)$. (b) Correlation between abnormal sperm head morphology and tail moment of treated rats with $\mathrm{r}^{2}=0.789(P<0.01)$. (c) Correlation between abnormal sperm head morphology and olive tail moment of treated rats with $\mathrm{r}^{2}=0.765(P<0.01)$. (d) Correlation between abnormal sperm head morphology and tail DNA of treated rats with $\mathrm{r}^{2}=0.787(P<0.01)$.

ages found in rat sperm induced by FNT. OP can cause DNA damage in rat sperm through the oxidative stress mechanism $[9,35,37]$. Data from a human study have also shown that DNA damage occurred in agricultural workers exposed to a mixture of OPs [34]. Piña-Guzmán et al. [35] reported that methyl parathion acted as an alkylating agent that caused changes in nuclear protamine structure. These changes would give the opportunity for ROS to attack the phosphate in DNA, thus breaking the DNA strand [35].

Treatment with antioxidant agents may counteract the abnormalities in sperm characteristic of OP exposures. In line with past studies, our results demonstrated that TRF improved the sperm characteristics by increasing the sperm count, motility, viability, and morphology, which might have been due to its antioxidant properties.
Supplementation with propolis, which contains a high level of vitamin $\mathrm{C}$, improved the sperm quality by increasing the sperm count and motility in chlorpyrifostreated rats through a reduction in ROS formation [16]. The combination of vitamins $\mathrm{E}$ and $\mathrm{C}$ also improved the percentage of sperm motility in methyl parathion-treated rats due to their scavenging activity of free radicals [50].

In the present study, the TRF consisted of $76 \%$ tocotrienol $(\alpha-, \beta-, \gamma-, \delta$-tocotrienol) and $24 \%$ tocopherol ( $\alpha$-tocopherol). Both tocotrienol and tocopherol possess ROS scavenging activities that would interrupt the propagation of a free radical chain reaction. However, tocotrienol was found to be more potent as an antioxidant in biological membranes compared with tocopherol due to its chromanol nucleus and unsaturated isoprenoid side chain [46]. Furthermore, previous research has also 
found that $\alpha$ - and $\gamma$-tocotrienol possess higher antioxidant activities compared with $\alpha$-tocopherol due to their differences in tail structure and also their powerful ability in recycling $\alpha$ - and $\gamma$-tocotrienoxyl (chromanoxyl radical) in biological membranes compared with $\alpha$-tocopherol [32, 40].

Therefore, in the TRF supplementation group, the SOD activity and GSH levels were increased due to the utilization of exogenous antioxidants in combating free radicals. These results supported previous research done by Ben Abdallah et al. [3], who found that the combination of vitamins $\mathrm{C}$ and $\mathrm{E}$ can enhance the endogenous antioxidant levels in rats with dimethoate-induced sperm damage. Though tocopherol has higher bioavailability compared with tocotrienol, a small concentration of tocotrienol is adequate to combat free radicals oxidative damage [19]. Tocotrienol and tocopherol are lipid-soluble molecules that bind extensively to the phospholipids of the biological membrane [39]. This characteristic facilitates the binding of both tocotrienol and tocopherol to the sperm membrane due to its high levels of PUFAs. Thus, in the present study, both tocotrienol and tocopherol might have had protective effects against sperm damage induced by FNT. However, due to differences in bioavailability, $\alpha$-tocopherol might be provide the first line defence mechanism followed by the greater effects of tocotrienol in scavenging free radicals, which may provide more promising effects in attenuating the sperm damage induced by FNT.

Supplementation with TRF also showed the potential to reduce sperm DNA damage by lowering the TL, TM, OTM, and percentage of tail DNA in rats treated with FNT. TRF may assuage the DNA damage in OP poisoning due to its ability as a potent antioxidant. The combination of vitamins $\mathrm{C}$ and $\mathrm{E}$ reduced sperm DNA damage through their ability to combat the ROS generation in rats induced by dimethoate [3]. Melatonin has been proposed to protect germ cells from oxidative stress rather than to have a direct effect on sperm in the epididymis, thus reducing the percentage of DNA damaged in diazonin-treated rats [37]. Our results are also consistent with previous research that found TRF from palm oil reduced DNA damage by inhibiting the formation of ROS in diabetic rats [8]. Furthermore, supplementation with TRF in human adults has been found to decrease DNA damage through its antioxidant function and by activation of signaling molecules in repairing the DNA [10].

Sperm DNA damage or expression of genetic materi- als may also influence sperm head abnormalities [53]. In the present study, a significant correlation was found between abnormal sperm head morphology and the sperm DNA damage in experimental groups. The results also showed that FNT increased sperm DNA damage, which leads to an increase in sperm head abnormalities, while supplementation with TRF in FNT-treated rats reduced both abnormalities. Therefore, this is clear evidence that increased abnormal sperm head morphology in FNT-treated rats might be due to the sperm DNA damage. This finding supports research done by Trivedi et al. [47], who found that sperm DNA damage induced by doxorubicin may influence sperm head abnormalities but that not many agents share the same mechanism. Some agents may not be depicting the sperm head morphology but instead may be causing sperm DNA damage [47].

In conclusion, this study demonstrated that palm oil TRF showed the potential to reduce the detrimental effects caused by FNT on sperm in Sprague-Dawley rats, which might be the result of its antioxidant properties. Therefore, further studies are warranted to clarify the molecular mechanisms of palm oil TRF supplementation in improving sperm quality following FNT exposure.

\section{Acknowledgments}

The authors would like to thank the lecturers, researchers, and staff of the Program of Biomedical Science, School of Diagnostic and Applied Health Sciences, Faculty of Health Sciences, Universiti Kebangsaan Malaysia, and those who directly or indirectly supported this research.

\section{References}

1. Ahmad, N.S., Khalid, B.A., Luke, D.A., and Ima Nirwana, S. 2005. Tocotrienol offers better protection than tocopherol from free radical-induced damage of rat bone. Clin. Exp. Pharmacol. Physiol. 32: 761-770. [Medline] [CrossRef]

2. Aitken, R.J. and De Iuliis, G.N. 2010. On the possible origins of DNA damage in human spermatozoa. Mol. Hum. Reprod. 16: 3-13. [Medline] [CrossRef]

3. Ben Abdallah, F., Fetoui, H., Zribi, N., Fakfakh, F., and Ammar-Keskes, L. 2012. Antioxidant supplementations in vitro improve rat sperm parameters and enhance antioxidant enzyme activities against dimethoate-induced sperm damages. Andrologia 44: 272-279. [Medline] [CrossRef]

4. Bebb, R.A., Anawalt, B.D., Christensen, R.B., Paulsen, C.A., Bremner, W.J., and Matsumoto, A.M. 1996. Combined administration of levonorgestrel and testosterone induces more rapid and effective suppression of spermatogenesis 
than testosterone alone: a promising male contraceptive approach. J. Clin. Endocrinol. Metab. 81: 757-762. [Medline]

5. Beyer, W.F. Jr. and Fridovich, I. 1987. Assaying for superoxide dismutase activity: some large consequences of minor changes in conditions. Anal. Biochem. 161: 559-566. [Medline] [CrossRef]

6. Budin, S.B., Han, C.M., Jayusman, P.A., and Taib, I.S. 2012. Tocotrienol rich fraction prevents fenitrothion induced pancreatic damage by restoring antioxidant status. Pak. J. Biol. Sci. 15: 517-523. [Medline] [CrossRef]

7. Budin, S.B., Han, K.J., Jayusman, P.A., Taib, I.S., Ghazali, A.R., and Mohamed, J. 2013. Antioxidant Activity of Tocotrienol Rich Fraction Prevents Fenitrothion-induced Renal Damage in Rats. J. Toxicol. Pathol. 26: 111-118. [Medline] [CrossRef]

8. Budin, S.B., Othman, F., Louis, S.R., Bakar, M.A., Das, S., and Mohamed, J. 2009. The effects of palm oil tocotrienolrich fraction supplementation on biochemical parameters, oxidative stress and the vascular wall of streptozotocin-induced diabetic rats. Clinics (Sao Paulo) 64: 235-244. [Medline] [CrossRef]

9. Burruel, V.R., Raabe, O.G., Overstreet, J.W., Wilson, B.W., and Wiley, L.M. 2000. Paternal effects from methamidophos administration in mice. Toxicol. Appl. Pharmacol. 165: 148157. [Medline] [CrossRef]

10. Chin, S.F., Hamid, N.A.A., Latiff, A.A., Zakaria, Z., Mazlan, M., Yusof, Y.A.M., Karim, A.A., Ibahim, J., Hamid, Z., and Ngah, W.Z.W. 2008. Reduction of DNA damage in older healthy adults by Tri E Tocotrienol supplementation. Nutrition 24: 1-10. [Medline] [CrossRef]

11. Dizdaroglu, M., Nackerdien, Z., Chao, B.C., Gajewski, E., and Rao, G. 1991. Chemical nature of in vivo DNA base damage in hydrogen peroxide-treated mammalian cells. Arch. Biochem. Biophys. 285: 388-390. [Medline] [CrossRef]

12. Ecobichon, D.J., Ozere, R.L., Reid, E., and Crocker, J.F.S. 1977. Acute fenitrothion poisoning. Can. Med. Assoc. J. 116: 377-379. [Medline]

13. Eitsuka, T., Nakagawa, K., and Miyazawa, T. 2006. Downregulation of telomerase activity in DLD-1 human colorectal adenocarcinoma cells by tocotrienol. Biochem. Biophys. Res. Commun. 348: 170-175. [Medline] [CrossRef]

14. Elhalwagy, M.E.A., Darwish, N.S., and Zaher, E.M. 2008. Prophylactic effect of green tea polyphenols against liver and kidney injury induced by fenitrothion insecticide. Pestic. Biochem. Physiol. 91: 81-89. [CrossRef]

15. Ellman, G.L. 1959. Tissue sulfhydryl groups. Arch. Biochem. Biophys. 82: 70-77. [Medline] [CrossRef]

16. ElMazoudy, R.H., Attia, A.A., and El-Shenawy, N.S. 2011. Protective role of propolis against reproductive toxicity of chlorpyrifos in male rats. Pestic. Biochem. Physiol. 101: 175-181. [CrossRef]

17. Hughes, C.M., Lewis, S.E., McKelvey-Martin, V.J., and Thompson, W. 1996. A comparison of baseline and induced DNA damage in human spermatozoa from fertile and infertile men, using a modified comet assay. Mol. Hum. Reprod. 2: 613-619. [Medline] [CrossRef]

18. Kamalakkannan, N. and Prince, P.S. 2003. Hypoglycaemic effect of water extracts of Aegle marmelos fruits in streptozotocin diabetic rats. J. Ethnopharmacol. 87: 207-210. [Medline] [CrossRef]

19. Khanna, S., Patel, V., Rink, C., Roy, S., and Sen, C.K. 2005. Delivery of orally supplemented alpha-tocotrienol to vital organs of rats and tocopherol-transport protein deficient mice. Free Radic. Biol. Med. 39: 1310-1319. [Medline] [CrossRef]

20. Khanna, S., Roy, S., Ryu, H., Bahadduri, P., Swaan, P.W., Ratan, R.R., and Sen, C.K. 2003. Molecular basis of vitamin E action: tocotrienol modulates 12-lipoxygenase, a key mediator of glutamate-induced neurodegeneration. J. Biol. Chem. 278: 43508-43515. [Medline] [CrossRef]

21. Klinefelter, G.R., Strader, L.F., Suarez, J.D., and Roberts, N.L. 2002. Bromochloroacetic acid exerts qualitative effects on rat sperm: implications for a novel biomarker. Toxicol. Sci. 68: 164-173. [Medline] [CrossRef]

22. Krishnamoorthy, G., Venkataraman, P., Arunkumar, A., Vignesh, R.C., Aruldhas, M.M., and Arunakaran, J. 2007. Ameliorative effect of vitamins (alpha-tocopherol and ascorbic acid) on PCB (Aroclor 1254) induced oxidative stress in rat epididymal sperm. Reprod. Toxicol. 23: 239-245. [Medline] [CrossRef]

23. Levine, R.L., Garland, D., Oliver, C.N., Amici, A., Climent, I., Lenz, A.G., Ahn, B.W., Shaltiel, S., and Stadtman, E.R. 1990. Determination of carbonyl content in oxidatively modified proteins. Methods Enzymol. 186: 464-478. [Medline] [CrossRef]

24. Lowry, O.H., Rosebrough, N.J., Farr, A.L., and Randall, R.J. 1951. Protein measurement with the Folin phenol reagent. $J$. Biol. Chem. 193: 265-275. [Medline]

25. Lukaszewicz-Hussain, A. 2010. Role of oxidative stress in organophosphate insecticide toxicity - Short review. Pestic. Biochem. Physiol. 98: 145-150. [CrossRef]

26. Matough, F.A., Budin, S.B., Hamid, Z.A., Louis, S.R., Alwahaibi, N., and Mohamed, J. 2012. Palm vitamin E reduces oxidative stress, and physical and morphological alterations of erythrocyte membranes in streptozotocin-induced diabetic rats. Oxid. Antioxid. Med. Sci. 1: 59-68.

27. Meeker, J.D., Singh, N.P., Ryan, L., Duty, S.M., Barr, D.B., Herrick, R.F., Bennett, D.H., and Hauser, R. 2004. Urinary levels of insecticide metabolites and DNA damage in human sperm. Hum. Reprod. 19: 2573-2580. [Medline] [CrossRef]

28. Milatovic, D., Gupta, R.C., and Aschner, M. 2006. Anticholinesterase toxicity and oxidative stress. Scientific WorldJournal 6: 295-310. [Medline] [CrossRef]

29. Okahashi, N., Sano, M., Miyata, K., Tamano, S., Higuchi, H., Kamita, Y., and Seki, T. 2005. Lack of evidence for endocrine disrupting effects in rats exposed to fenitrothion in utero and from weaning to maturation. Toxicology 206: 17-31. [Medline] [CrossRef]

30. Okamura, A., Kamijima, M., Ohtani, K., Yamanoshita, O., Nakamura, D., Ito, Y., Miyata, M., Ueyama, J., Suzuki, T., Imai, R., Takagi, K., and Nakajima, T. 2009. Broken sperm, cytoplasmic droplets and reduced sperm motility are principal markers of decreased sperm quality due to organophosphorus pesticides in rats. J. Occup. Health 51: 478-487. [Medline] [CrossRef] 
31. Okamura, A., Kamijima, M., Shibata, E., Ohtani, K., Takagi, K., Ueyama, J., Watanabe, Y., Omura, M., Wang, H., Ichihara, G., Kondo, T., and Nakajima, T. 2005. A comprehensive evaluation of the testicular toxicity of dichlorvos in Wistar rats. Toxicology 213: 129-137. [Medline] [CrossRef]

32. Packer, L., Weber, S.U., and Rimbach, G. 2001. Molecular aspects of alpha-tocotrienol antioxidant action and cell signalling. J. Nutr. 131: 369S-373S. [Medline]

33. Padungtod, C., Hassold, T.J., Millie, E., Ryan, L.M., Savitz, D.A., Christiani, D.C., and Xu, X. 1999. Sperm aneuploidy among Chinese pesticide factory workers: scoring by the FISH method. Am. J. Ind. Med. 36: 230-238. [Medline] [CrossRef]

34. Pérez-Herrera, N., Polanco-Minaya, H., Salazar-Arredondo, E., Solís-Heredia, M.J., Hernández-Ochoa, I., Rojas-García, E., Alvarado-Mejía, J., Borja-Aburto, V.H., and QuintanillaVega, B. 2008. PON1Q192R genetic polymorphism modifies organophosphorous pesticide effects on semen quality and DNA integrity in agricultural workers from southern Mexico. Toxicol. Appl. Pharmacol. 230: 261-268. [Medline] [CrossRef]

35. Piña-Guzmán, B., Solís-Heredia, M.J., Rojas-García, A.E., Urióstegui-Acosta, M., and Quintanilla-Vega, B. 2006. Genetic damage caused by methyl-parathion in mouse spermatozoa is related to oxidative stress. Toxicol. Appl. Pharmacol. 216: 216-224. [Medline] [CrossRef]

36. Sakai, M., Okabe, M., Tachibana, H., and Yamada, K. 2006. Apoptosis induction by gamma-tocotrienol in human hepatoma Hep3B cells. J. Nutr. Biochem. 17: 672-676. [Medline] [CrossRef]

37. Sarabia, L., Maurer, I., and Bustos-Obregón, E. 2009. Melatonin prevents damage elicited by the organophosphorous pesticide diazinon on mouse sperm DNA. Ecotoxicol. Environ. Saf. 72: 663-668. [Medline] [CrossRef]

38. Seed, J., Chapin, R.E., Clegg, E.D., Dostal, L.A., Foote, R.H., Hurtt, M.E., Klinefelter, G.R., Makris, S.L., Perreault, S.D., Schrader, S., Seyler, D., Sprando, R., Treinen, K.A., Veeramachaneni, D.N., and Wise, L.D. 1996. Methods for assessing sperm motility, morphology, and counts in the rat, rabbit, and dog: a consensus report. ILSI Risk Science Institute Expert Working Group on Sperm Evaluation. Reprod. Toxicol. 10: 237-244. [Medline] [CrossRef]

39. Sen, C.K., Khanna, S., and Roy, S. 2006. Tocotrienols: Vitamin E beyond tocopherols. Life Sci. 78: 2088-2098. [Medline] [CrossRef]

40. Serbinova, E., Kagan, V., Han, D., and Packer, L. 1991. Free radical recycling and intramembrane mobility in the antioxidant properties of alpha-tocopherol and alpha-tocotrienol. Free Radic. Biol. Med. 10: 263-275. [Medline] [CrossRef]

41. Shibata, A., Nakagawa, K., Sookwong, P., Tsuzuki, T., Oikawa, S., and Miyazawa, T. 2008. Tumor anti-angiogenic effect and mechanism of action of delta-tocotrienol. Biochem. Pharmacol. 76: 330-339. [Medline] [CrossRef]

42. Sikka, S.C. 2004. Role of oxidative stress and antioxidants in andrology and assisted reproductive technology. J. Androl.
25: 5-18. [Medline]

43. Stocks, J. and Dormandy, T.L. 1971. The autoxidation of human red cell lipids induced by hydrogen peroxide. $B r . J$. Haematol. 20: 95-111. [Medline] [CrossRef]

44. Taib, I.S., Budin, S.B., Ghazali, A.R., Jayusman, P.A., Louis, S.R., and Mohamed, J. 2013. Fenitrothion induced oxidative stress and morphological alterations of sperm and testes in male Sprague-Dawley rats. Clinics (Sao Paulo) 68: 93-100. [Medline] [CrossRef]

45. Tamura, H., Maness, S.C., Reischmann, K., Dorman, D.C., Gray, L.E., and Gaido, K.W. 2001. Androgen receptor antagonism by the organophosphate insecticide fenitrothion. Toxicol. Sci. 60: 56-62. [Medline] [CrossRef]

46. Traber, M.G. and Atkinson, J. 2007. Vitamin E, antioxidant and nothing more. Free Radic. Biol. Med. 43: 4-15. [Medline] [CrossRef]

47. Trivedi, P., Kushwaha, S., Tripathi, D., and Jena, G. 2010. Evaluation of male germ cell toxicity in rats: Correlation between sperm head morphology and sperm comet assay. Mutat. Res-Gen. Toxicol. En. 703: 115-121.

48. Uygun, U., Koksel, H., and Atli, A. 2005. Residue levels of malathion and its metabolites and fenitrothion in postharvest treatment wheat during storage, milling and baking. Food Chem. 92: 643-647. [CrossRef]

49. Uzun, F.G., Kalender, S., Durak, D., Demir, F., and Kalender, Y. 2009. Malathion-induced testicular toxicity in male rats and the protective effect of vitamins C and E. Food Chem. Toxicol. 47: 1903-1908. [Medline] [CrossRef]

50. Uzunhisarcikli, M., Kalender, Y., Dirican, K., Kalender, S., Ogutcu, A., and Buyukkomurcu, F. 2007. Acute,subacute and subchronic administration of methyl parathion-induced testicular damage in male rats and protective role of vitamins C and E. Pestic. Biochem. Physiol. 87: 115-122. [CrossRef]

51. Valko, M., Rhodes, C.J., Moncol, J., Izakovic, M., and Mazur, M. 2006. Free radicals, metals and antioxidants in oxidative stress-induced cancer. Chem. Biol. Interact. 160: 1-40. [Medline] [CrossRef]

52. Villaverde, J., Hildebrandt, A., Martínez, E., Lacorte, S., Morillo, E., Maqueda, C., Viana, P., and Barceló, D. 2008. Priority pesticides and their degradation products in river sediments from Portugal. Sci. Total Environ. 390: 507-513. [Medline] [CrossRef]

53. Wyrobek, A. and Bruce, W. 1975. Chemical induction of sperm abnormalities in mice. P. Natl. Acad. Sci-Biol. 72: 4425-4429.

54. Yap, W.N., Zaiden, N., Tan, Y.L., Ngoh, C.P., Zhang, X.W., Wong, Y.C., Ling, M.T., and Yap, Y.L. 2010. Id1, inhibitor of differentiation, is a key protein mediating anti-tumor responses of gamma-tocotrienol in breast cancer cells. Cancer Lett. 291: 187-199. [Medline] [CrossRef]

55. Yucra, S., Rubio, J., Gasco, M., Gonzales, C., Steenland, K., and Gonzales, G.F. 2006. Semen quality and reproductive sex hormone levels in Peruvian pesticide sprayers. Int. J. Occup. Environ. Health 12: 355-361. [Medline] [CrossRef] 